\title{
Implications for photonic applications of diatom growth and frustule nanostructure changes in response to different light wavelengths
}

Su, Yanyan; Lundholm, Nina; Friis, Søren Michael Mørk; Ellegaard, Marianne

Published in:

Nano Research

Link to article, DOI:

doi 10.1007/s12274-015-0746-6

Publication date:

2015

Link back to DTU Orbit

Citation (APA):

Su, Y., Lundholm, N., Friis, S. M. M., \& Ellegaard, M. (2015). Implications for photonic applications of diatom growth and frustule nanostructure changes in response to different light wavelengths. Nano Research, 8(7), 2363-2372. https://doi.org/doi 10.1007/s12274-015-0746-6

\section{General rights}

Copyright and moral rights for the publications made accessible in the public portal are retained by the authors and/or other copyright owners and it is a condition of accessing publications that users recognise and abide by the legal requirements associated with these rights.

- Users may download and print one copy of any publication from the public portal for the purpose of private study or research.

- You may not further distribute the material or use it for any profit-making activity or commercial gain

- You may freely distribute the URL identifying the publication in the public portal 


\title{
Implications for photonic applications of diatom growth and frustule nanostructure changes in response to different light wavelengths
}

\author{
Yanyan Su$(\varangle)$, Nina Lundholm², Søren M.M. Friis ${ }^{3}$, and Marianne Ellegaard ${ }^{1}$
}

Nano Res., Just Accepted Manus cript • DOI 10.1007/s12274-015-0746-6

http://www.thenanoresearch.com on February 13, 2015

(C) Tsinghua University Press 2015

\section{Just Accepted}

\begin{abstract}
This is a "Just Accepted" manuscript, which has been examined by the peer-review process and has been accepted for publication. A "Just Accepted" manuscript is published online shortly after its acceptance, which is prior to technical editing and formatting and author proofing. Tsinghua University Press (TUP) provides "Just Accepted" as an optional and free service which allows authors to make their results available to the research community as soon as possible after acceptance. After a manuscript has been technically edited and formatted, it will be removed from the "Just Accepted" Web site and published as an ASAP article. Please note that technical editing may introduce minor changes to the manuscript text and/or graphics which may affect the content, and all legal disclaimers that apply to the journal pertain. In no event shall TUP be held responsible for errors or consequences arising from the use of any information contained in these "Just Accepted" manuscripts. To cite this manuscript please use its Digital Object Identifier (DOI $\left.{ }^{\circ}\right)$, which is identical for all formats of publication.
\end{abstract}




\section{Implications for photonic applications of diatom growth and frustule nanostructure changes in response to different light wavelengths}

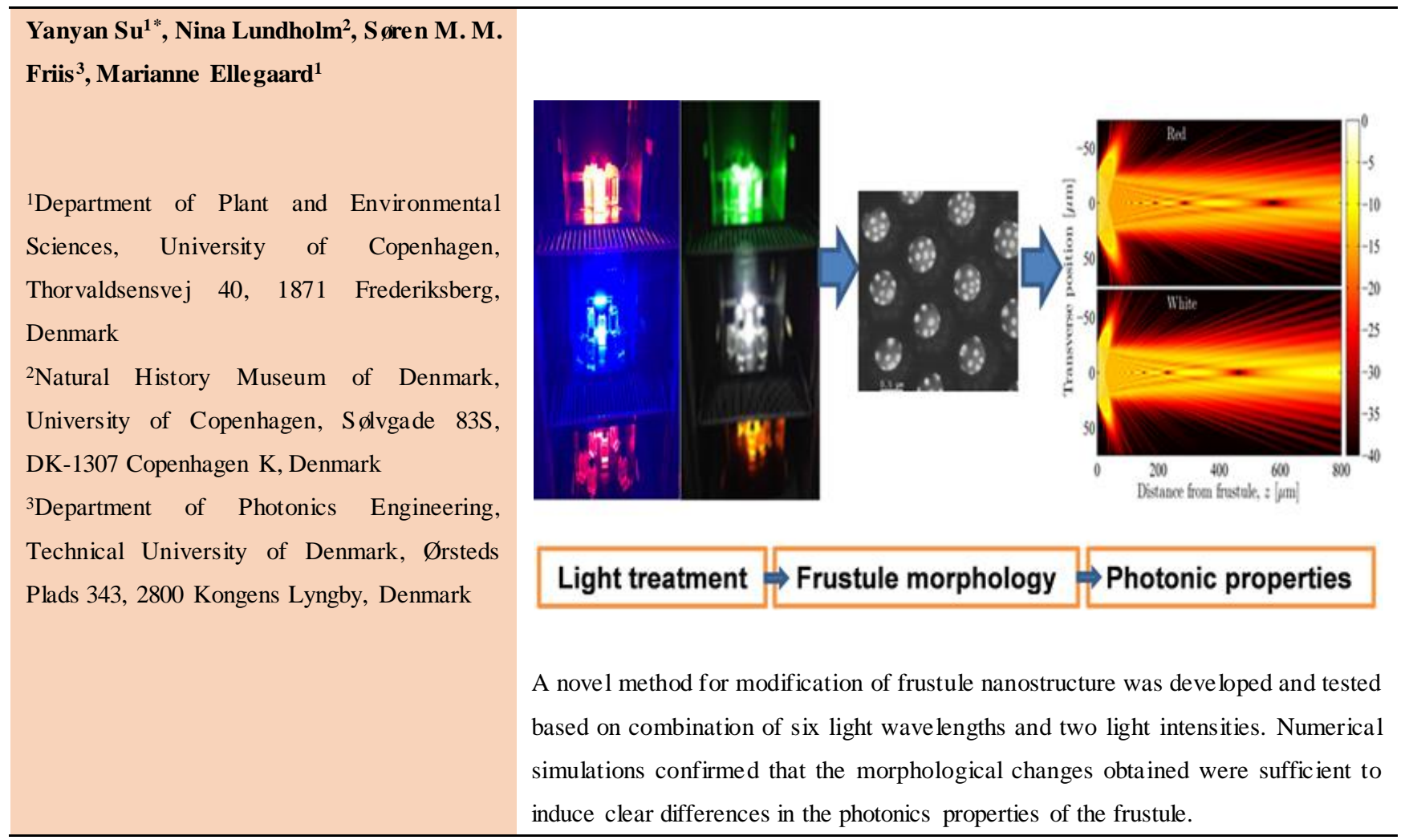

* Corresponding author: Tel: +45 35320437. Email: yanyansu@plen.ku.dk

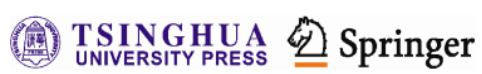




\title{
Implications for photonic applications of diatom growth and frustule nanostructure changes in response to different light wavelengths
}

\author{
Yanyan Su$(\bowtie)$, Nina Lundholm², Søren M.M. Friis ${ }^{3}$, and Marianne Ellegaard ${ }^{1}$ \\ ${ }^{1}$ Department of Plant and EnvironmentalSciences, University of Copenhagen, Thorvaldsensvej 40, 1871 Frederiksberg, Denmark \\ ${ }^{2}$ Natural History Museum of Denmark, University of Copenhagen, Sølvgade 83S, DK-1307 Copenhagen K, Denmark \\ ${ }^{3}$ Department of Photonics Engineering, Technical University of Denmark, Ørsteds Plads 343, 2800 Kongens Lyngby, Denmark
}

\author{
Received: day month year \\ Revised: day month year \\ Accepted: day month year \\ (automatically inserted by \\ the publisher) \\ (C) Tsinghua University Press \\ and Springer-Verlag Berlin \\ Heidelberg 2014

\section{KEYWORDS} \\ Coscinodiscus granii, light \\ wavelength, light \\ intensity, frustule \\ nanostructure, growth \\ rate, photonic properties
}

\begin{abstract}
Diatoms are unicellular algae enclosed in intricate bio-silicified walls with repetitive nanostructures in a size range which makes them potentially relevant for a broad spectrum of industrial applications. How to optimize the nano-scale structures of the frustule for utilization of diatoms in nanotechnology is one of the technological challenges for these applications. Light is one of the most important abiotic factors for algal photosynthetic growth, and the frustule may play an important role in mediating light for these biological functions, as well as being central for its nano-technological applications. In this study, we tested the influence of light quality on the nanostructure of the frustule of Coscinodiscus granii and compared this to growth rate response. The results showed that colored light (red, yellow, green and blue) at $300 \mu \mathrm{mol}$ photons $\mathrm{m}^{-2} \mathrm{~s}^{-1}$ resulted in a statistically significant change in nanostructure compared to white light. Green light at $100 \mu \mathrm{mol}$ photon $\mathrm{m}^{-2} \mathrm{~s}^{-1}$ led to a significant decrease in mean frustule diameter and mean foramen diameter. Numerical simulations confirmed that the morphological changes obtained were sufficient to induce clear differences in the photonics properties of the frustule. The wavelength had no effect on the growth rate at high light intensity $\left(300 \mu \mathrm{mol}\right.$ photons $\left.\mathrm{m}^{-2} \mathrm{~s}^{-1}\right)$. However, at $100 \mu \mathrm{mol}$ photons $\mathrm{m}^{-2} \mathrm{~s}^{-1}$, yellow, red-orange and green light resulted in significantly lower maximum growth rates than the other wavelengths. This response of the frustule structure to different light treatment indicates the possibility of a light-based frustule nanostructure manipulation method, which is simple and environmentally friendly.
\end{abstract}

\section{Introduction}

Diatoms are a major group of eukaryotic, unicellular algae that are ubiquitously found in almost every water habitat on earth. It is estimated that they may contribute up to $40 \%$ of primary productivity in marine ecosystems and $20 \%$ of global carbon fixation $[1,2]$. The number of recognized diatom species is $10.000-20.000$, but it is estimated that there may be more than 200.000, with cell

$\overline{\text { Address correspondence to Yanyan }} \mathrm{Su}$, yanyansu@ plen.ku.dk 
diameters ranging from $2 \mu \mathrm{m}$ to ca. $1 \mathrm{~mm}$ [3]. Diatoms are thus one of the most successful groups of organisms in the world, appearing first in the fossil record about 200 million years ago [4, 5]. Compared with other unicellular algae, the hallmark of diatoms is their intricate cell walls made of hydrated amorphous silica [4, 6]. The frustule is composed of two parts, each including one transparent petri-dish like valve with repetitive nanostructures [6, 7]. Due to the special optical properties of their frustule structure, diatoms are regarded as a green nanomaterial and may have properties of natural photonic crystals with broad industrial application potential, such as micro lenses, UV protection, optical sensors for volatile substances [8-10]. Utilization of these frustules could reduce the production cost compared with traditional artificial crystal materials. Previous studies have indicated that the proposed diatom photonic applications depend on their precise nanostructure [11-13]. Therefore control and manipulation of the nanostructures is presented as one of the key technical challenges $[9,14]$. Previous studies have tested chemical modification methods such as atomic layer deposition, addition of certain metal ion (Ge and $\mathrm{Ni}$ ) into the medium [15], etching by hydrofluoric acid or strong alkali treatment [16-19]. However, these chemical-based methods might cause secondary contamination, thus possible biological modification methods are preferable. Frustule biosilicification processes have been investigated in detail at the molecular level [5], but few studies focus on the influence of abiotic factors which affect diatom growth, on the frustule morphology [20,21]. Light is an essential environmental factor for photosynthetic organisms and although little is known about the biological functions of the frustule [22], one possibility is that it plays a role related to light such as selecting confined light to pass the frustules or focusing the light to benefit photosynthesis $[10,23$, 24]. If this is the case, we would expect different light conditions, especially light wavelengths, to affect the self-assembled nanostructure of the frustule.

In this study, for the first time, the responses of the frustule nanostructure to different light wavelengths within the visible light range at two intensities were studied. Diatom growth rate was tested to determine if there is a link between the morphological changes in nanostructure and growth rate, e.g. whether the changes are driven merely by changes in division rate. Furthermore, growth rate is an important parameter for future industrial production of diatom frustules. Light conditions which have significant effect on the frustule morphology and/or growth rate were identified. To test the significance of the observed changes in frustule nanostructure for future photonic applications, simulations of light propagation through simple models of frustules were carried out. Controlling light wavelengths could be an alternative method to manipulate the frustule morphology of the diatom, thereby broadening the application possibility and accelerating its industrial application.

\section{Results and Discussion}

\subsection{The influence of light wavelength and intensity on growth rate}

The growth pattern under all six different wavelengths was quite similar at $300 \mu \mathrm{mol}$ photons $\mathrm{m}^{-2} \mathrm{~s}^{-1}$ (Fig. 1a), and the mean maximum growth rates at $300 \mu \mathrm{mol}$ photons $\mathrm{m}^{-2} \mathrm{~s}^{-1}$ were statistically similar (analysis of variance, ANOVA, $\mathrm{p} \geq 0.05$ ). As shown in Fig. 1(b), at $100 \mu \mathrm{mol}$ photons $\mathrm{m}^{-2} \mathrm{~s}^{-1}$, the fastest growth was achieved under $\mathrm{B}$, and the mean maximum growth rate in declining order was Blue (B) $>$ Red (R) $>$ White $(W)>$ Green (G) $>$ Red-Orange $(\mathrm{RO})>$ Yellow $(\mathrm{Y})$ (see supplementary information). Significant difference was found among them (ANOVA, $\mathrm{p} \leq 0.05$ ). Post hoc tests (Bonferroni-Holm) showed the growth rate at $B$ to be significantly higher than at $G, R O$ and $Y$ light $(p \leq 0.05)$, and no significant difference existed between $\mathrm{B}, \mathrm{R}$ and $\mathrm{W}$. Previous studies have found that responses in algal growth, pigment concentration and photosynthesis rate to different light wavelengths varied, being species-specific and depending on the size of the cells $[25,26]$. Similar to our study, growth rate and photosynthesis efficiency for Coscinodiscus radiatus and Thalassiosira pseudonana, were highest at violet-blue to blue light compared with other light treatments in the previous work $[11,25,27]$. One of the underlying reasons for this phenomenon might be enhancement of chlorophyll synthesis by blue light due to the light adaptation in natural water [28, 
29]. Besides, based on the evolutionary history of microalgae, Keeling reported the preference of microalgae to grow under either blue $(420-470 \mathrm{~nm})$ or red $(660 \mathrm{~nm})$ [30]. Schulze et al. also reported that the major growth favorable wavelengths for chlorophyll-a containing microalgae are within the range of 420-470 $\mathrm{nm}$ (B) and/or 660-680 $\mathrm{nm}(\mathrm{R})$ [31]. This correlates well with our results.
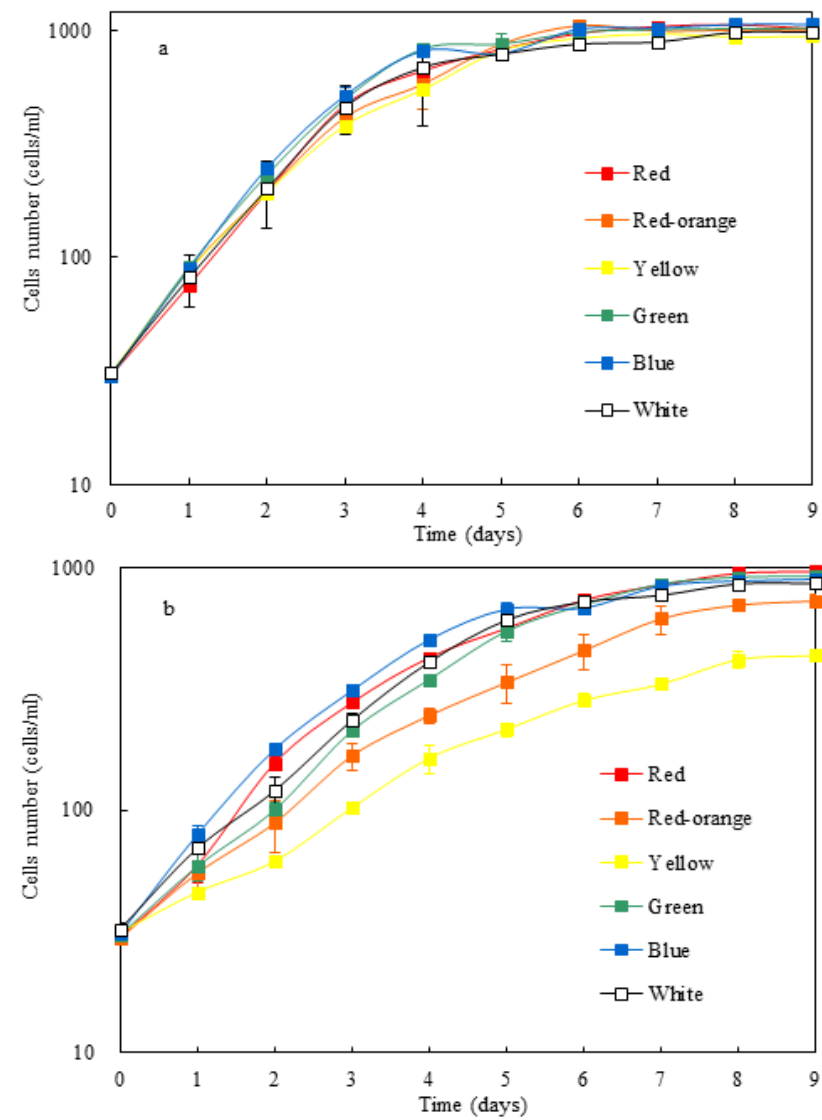

Figure 1 Growth curve of $C$. granii under six different light wavelengths at $300 \mu \mathrm{mol}$ photons $\mathrm{m}^{-2} \mathrm{~s}^{-1}$ (a) and $100 \mu \mathrm{mol}$ photons $\mathrm{m}^{-2} \mathrm{~s}^{-1}(\mathrm{~b})$. Error bars indicate standard deviation $(\mathrm{n}=3)$.

Light-emitting diodes (LEDs) are a promising, more sustainable light source for algal growth as they are mercury-free, long-lasting, and have fast-response and high conversion efficiency from electrical energy to photon energy [31,32]. In this study, no significant difference in maximum growth rate was found between $B$ and $R$ light at both 100 and $300 \mu \mathrm{mol}$ photons $\mathrm{m}^{-2} \mathrm{~s}^{-1}$. As red LED is more energy efficient than blue (yielding more photons per watt) [33], $\mathrm{R}$ light may be important for future industrial use of the diatom frustules demanding a production of diatoms in high quantities as it can support high grow rate and has low energy consumption. More importantly, R light at $300 \mu \mathrm{mol}$ photons $\mathrm{m}^{-2} \mathrm{~s}^{-1}$ led to the lowest foramen density and visible changes in photonics properties (see below).

In the present study, the lowest growth rate was obtained at $\mathrm{Y}$ light at an intensity of $100 \mu \mathrm{mol}$ photons $\mathrm{m}^{-2} \mathrm{~s}^{-1}$, similar to previous studies using Haslea ostrearia [11, 25]. However, at high irradiance (300 $\mu \mathrm{mol}$ photons $\mathrm{m}^{-2} \mathrm{~s}^{-1}$ ), the different wavelengths had no significant effect on the mean maximum growth rates. A possible explanation is that at 300 $\mu \mathrm{mol}$ photons $\mathrm{m}^{-2} \mathrm{~s}^{-1}$ the intensity has passed saturating light intensities [34], thus, all the wavelengths used here support optimal diatom growth.

The maximum growth rate of $C$. granii was highest at $300 \mu \mathrm{mol}$ photons $\mathrm{m}^{-2} \mathrm{~s}^{-1}$ at all six wavelengths, indicating that although $300 \mu \mathrm{mol}$ photons $\mathrm{m}^{-2} \mathrm{~s}^{-1}$ is a relatively high level of irradiance, it did not lead to lower growth rate than $100 \mu \mathrm{mol}$ photons $\mathrm{m}^{-2} \mathrm{~s}^{-1}$ by photoinhibition. These differences in the growth rates between 100 and $300 \mu \mathrm{mol}$ photons $\mathrm{m}^{-2} \mathrm{~s}^{-1}$ are significant ( $\mathrm{p} \leq 0.05)$, except for $\mathrm{W}$ light ( $\mathrm{p} \geq 0.05)$. It has previously been reported that for $\mathrm{W}$ light, $100 \mu \mathrm{mol}$ photons $\mathrm{m}^{-2} \mathrm{~s}^{-1}$ with continuous illumination was the optimum light intensity for $C$. granii [34]. This agrees with our finding of no significant difference in maximum growth rate between at 100 and $300 \mu \mathrm{mol}$ photons $\mathrm{m}^{-2} \mathrm{~s}^{-1}$ at $\mathrm{W}$ light. Compared to white light, cells grown in mono spectral light may need a higher intensity to supplement the deficiency in the other wavelengths.

\subsection{The influence of light wavelengths on diatom morphology}

The species-specific morphology of the silica frustule is the main diagnostic character for identifying diatom species. Coscinodiscus granii is a typical radial centric symmetric diatom (Fig. 2) with a circular valve and numerous foramens regularly distributed in an approximately hexagonal pattern, while also radiating out from the center on the surface of valve. The external part of the areola is covered by a silica membrane perforated by smaller pores (Fig. 2c). Three parameters, namely frustule diameter (Fig. 2a), foramen number in $10 \mu \mathrm{m}$ (Fig. 2b) and foramen diameter (Fig. 2c) were measured on TEM 
micrographs and the detailed results are summarized in Fig. 3.

At $100 \mu \mathrm{mol}$ photons $\mathrm{m}^{-2} \mathrm{~s}^{-1}$, colored light caused a slight decrease in frustule diameter compared to the control (W) light (Table S2 in supplementary material), but only the difference between frustule diameter of $\mathrm{W}(64.44 \pm 41.09 \mu \mathrm{m})$ and frustule diameter of $G(42.70 \pm 5.71 \mu \mathrm{m})$ light was statistically significant (Kruskall Wallis, $\mathrm{p} \leq 0.05$ ). At $300 \mu \mathrm{mol}$ photons $\mathrm{m}^{-2} \mathrm{~s}^{-1}$, no significant differences were found in mean diameter (Kruskall Wallis, $p \geq 0.05$ ). The repeatability of the results was shown by statistical analysis of two batches of experimental data by ANOVA or Kruskall Wallis test, which showed that no significant difference was found between the two data sets ( $p \geq 0.05$, Table S2). Differences in valve size may be driven by a gradual decrease in size during each cell division, with restitution to the initial sizes by auxospore formation [6], but as there was no direct relationship between high growth rate and small frustule diameter, the size reduction seen in this study is not only driven by division rate. Thus, for example, compared with control (W) light, G light led to $33.74 \%$ smaller average frustule diameter although no significant difference was found in maximum growth rate under $\mathrm{W}$ and $\mathrm{G}$ light $(\mathrm{p} \geq 0.05)$. For $\mathrm{R}, \mathrm{RO}, \mathrm{G}, \mathrm{B}$ and $\mathrm{W}$ light, the mean diameter of frustules cultivated at $100 \mu \mathrm{mol}$ photons $\mathrm{m}^{-2} \mathrm{~s}^{-1}$ seemed to be larger than at $300 \mu \mathrm{mol}$ photons $\mathrm{m}^{-2} \mathrm{~s}^{-1}$, but the difference was not significant $(p \geq 0.05)$. The largest frustule diameter of $C$. granii obtained in this study was around $105 \mu \mathrm{m}$, which is within the size spectrum previously reported of 40-200 $\mu \mathrm{m}$ [35]. Small cells generally have higher growth rates, a larger surface/volume ratio, and inherently superior ability to harvest light and nutrients under equilibrium conditions than larger cells, while larger algae cells may experience a lower stress by grazers [36]. It has previously been reported that a reduction in size is a common response when diatoms grow under stress conditions [36, 37]. Therefore, the slight size reduction of $C$. granii may be a consequence of environmental stress caused by colored light and high irradiance.

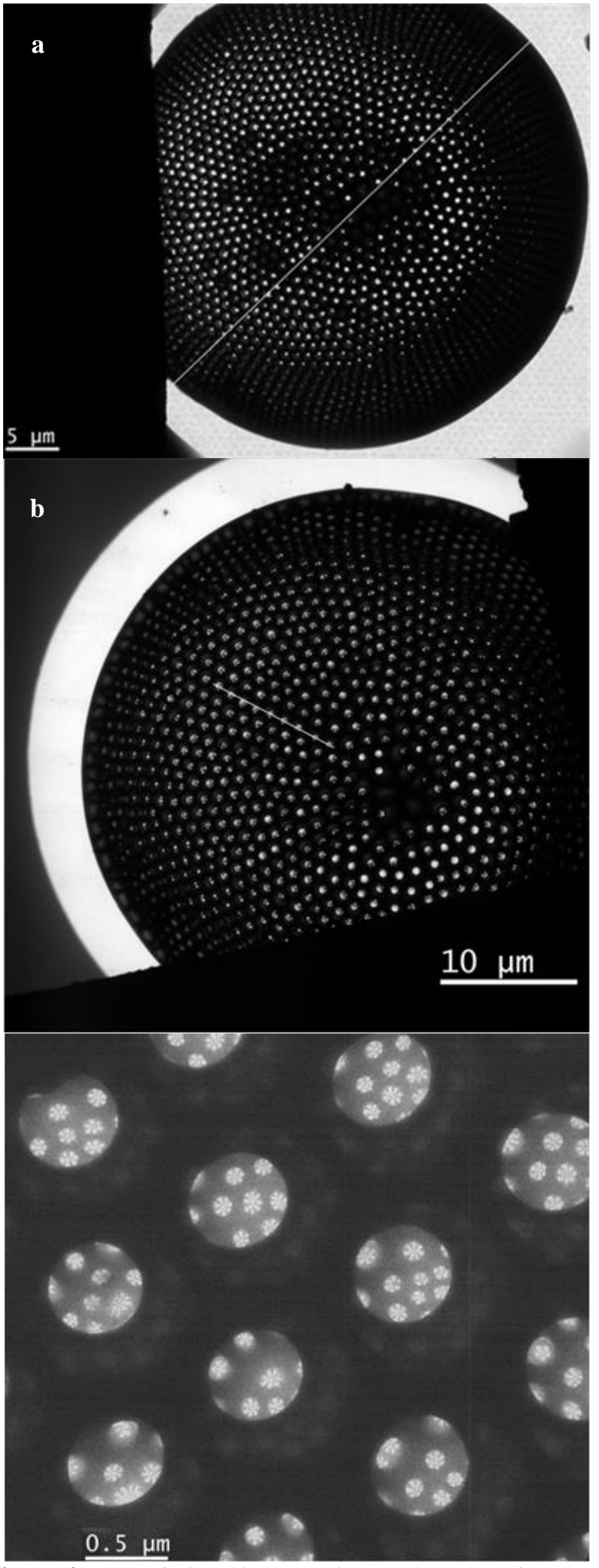

Figure 2 Transmission electron micrograph (TEM) image of internal surface of C. granii. (a) The frustule diameter; (b) Foramen number in $10 \mu \mathrm{m}$; (c) The size of the foramen.

The foramen density (Fig. 3b) showed a general trend 
of higher light intensity resulting in lower foramen density, except for $\mathrm{W}$ light. The $\mathrm{W}$ light source applied here has a broad spectrum that consists of all the visible wavelengths of light. The difference between such a $\mathrm{W}$ light source and a monochromatic source might explain the reversed trend in foramen density. The influence of the light intensity on the foramen density was also analyzed by a Kruskall Wallis test, which showed that for R, Y, G, B and W light, the differences between 100 and $300 \mu \mathrm{mol}$ photons $\mathrm{m}^{-2} \mathrm{~S}^{-1}$ were significant. At $100 \mu \mathrm{mol}$ photons $\mathrm{m}^{-2} \mathrm{~s}^{-1}$, no statistically significant differences were found among the different wavelengths (Kruskall Wallis, $\mathrm{p} \geq 0.05)$. At high irradiance ( $300 \mu \mathrm{mol}$ photons $\left.\mathrm{m}^{-2} \mathrm{~s}^{-1}\right)$, there were significant differences between $\mathrm{R}$ $(8.25 \pm 1.08 / 10 \mu \mathrm{m})$ and $W(9.39 \pm 0.59 / 10 \mu \mathrm{m})$ light, $Y$ $(8.44 \pm 0.60 / 10 \mu \mathrm{m})$ and $W$ light, $G(8.36 \pm 0.78 / 10 \mu \mathrm{m})$ and $\mathrm{W}$ light, $\mathrm{B}(8.73 \pm 0.42 / 10 \mu \mathrm{m})$ and $\mathrm{W}$ light as shown in Fig. $3 b$ (ANOVA, $p \leq 0.05$ ). Based on the above results, high irradiance (except with $\mathrm{W}$ light) will decrease the foramen density relative to lower light, and R, Y, G and B light at high irradiance will significantly decrease the foramen density, relative to white light. This offers a potential method to manipulate foramen density. Besides, all the wavelengths which led to significant change in frustule nanostructure supported high growth rate (shown in Fig. 1a). Although a significant effect on mean foramen density was obtained, there was a range of variability within each treatment (Fig. 3b). The simulations (see later) indicate that the achieved differences in mean foramen density have implications for the photonic properties of the frustule, but it is at present not clear what the implications of the range of variability are for these properties. It is notable that the variability in frustule diameter at $\mathrm{RO}$ and $\mathrm{G}$ light at both light intensities and at $B$ and $W$ light at $300 \mu \mathrm{mol}$ photons $\mathrm{m}^{-2} \mathrm{~s}^{-1}$ were relatively low (less than $10 \mu \mathrm{m}$ ), and the lowest variability in foramen density was found at $B$ light at $300 \mu \mathrm{mol}$ photons $\mathrm{m}^{-2} \mathrm{~s}^{-1}$, which means that relatively fixed frustule types were formed at these light treatments.

At all wavelengths the mean foramen diameters were below $550 \mathrm{~nm}$ (Fig. 3c) and a common trend for all six different wavelengths was that higher light intensity led to a smaller foramen diameter, but significant differences in foramen diameter were
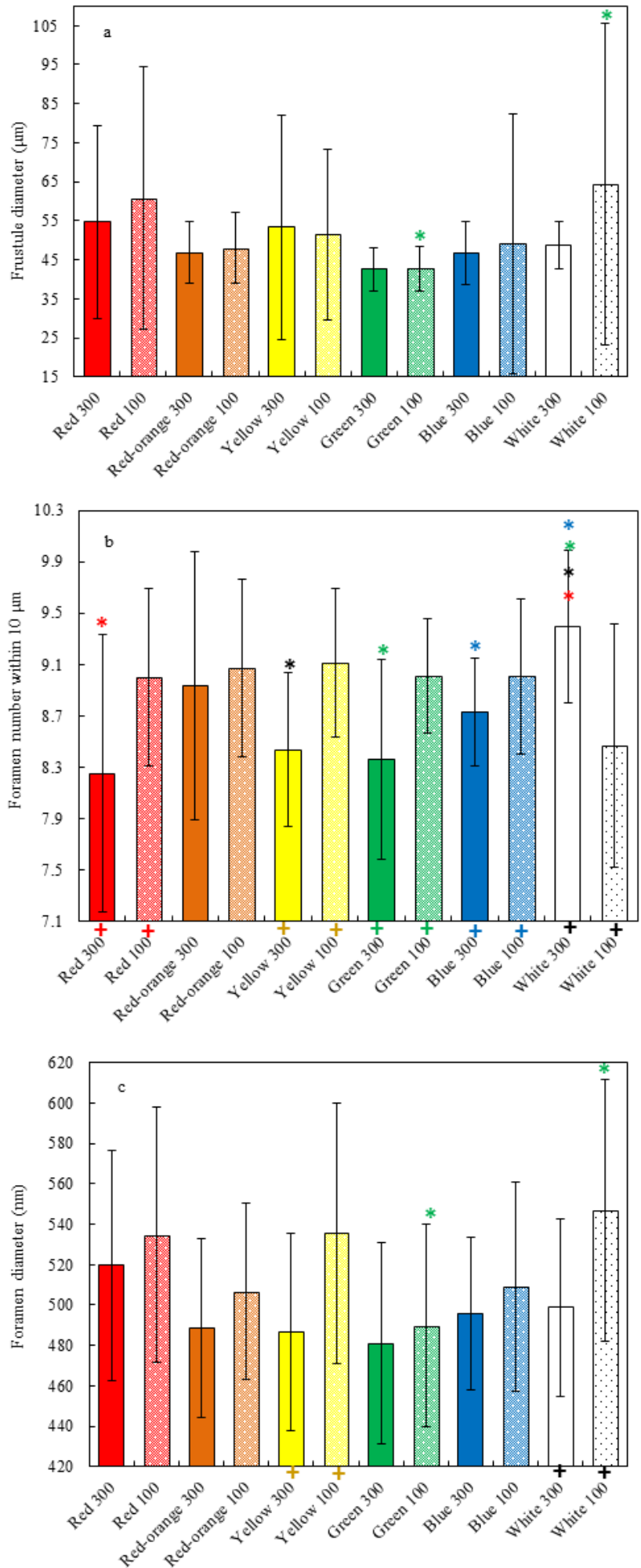

Figure 3 Frustule morphology of C. granii cultivated under different light wavelength at 100 and $300 \mu \mathrm{mol}$ photons $\mathrm{m}^{-2} \mathrm{~s}^{-1}$ ( $\mathrm{n}=20$ valves). (a) Frustule diameter; (b) Foramen number within $10 \mu \mathrm{m}$ on internal porous layer (foramen density); (c) Foramen diameter (internal porous layer). The symbol $(*)$ in the same color over histograms indicates that there was significant 
difference between each other. The symbol (+) below light treatments indicates that there were significant differences $(\mathrm{p} \leq 0.05)$ between the 100 and $300 \mu \mathrm{mol}$ photons $\mathrm{m}^{-2} \mathrm{~s}^{-1}$ irradiance of same wavelength.

found only between $\mathrm{W}(546.81 \pm 64.92 \mathrm{~nm})$ and $\mathrm{G}$ $(489.66 \pm 50.22 \mathrm{~nm})$ light at $100 \mu \mathrm{mol}$ photons $\mathrm{m}^{-2} \mathrm{~s}^{-1}$ (Kruskall Wallis, $\mathrm{p} \leq 0.05$ ). For different light intensities, statistical differences were found between 100 and $300 \mu \mathrm{mol}$ photons $\mathrm{m}^{-2} \mathrm{~s}^{-1}$ for $\mathrm{Y}$ and $\mathrm{W}$ light. The smallest mean foramen diameter was found with G light at $300 \mu \mathrm{mol}$ photons $\mathrm{m}^{-2} \mathrm{~s}^{-1}$ while the largest foramen diameter was found with control (W) light at $100 \mu \mathrm{mol}$ photons $\mathrm{m}^{-2} \mathrm{~s}^{-1}$.

Few studies are available on morphological changes other than frustule size, especially biologically based frustule modification. Hansen et al. reported that increasing the temperature from $4{ }^{\circ} \mathrm{C}$ to $15{ }^{\circ} \mathrm{C}$ led to a reduction of about $20 \%$ in foramen density for the pennate diatom Pseudo-nitzschia seriata [20]. In $P$. multiseries, the number of foramen rows decreased from $3-4$ at $5{ }^{\circ} \mathrm{C}$ and $15^{\circ} \mathrm{C}$, to $2-3$ rows at $25{ }^{\circ} \mathrm{C}$ [21]. In Thallasiosira antarctica and Porosira glacialis, the foramina were greatly constricted at $-1.5 \quad{ }^{\circ} \mathrm{C}$ compared with at $4{ }^{\circ} \mathrm{C}$ with open foramina [38] and in Thalassiosira weissflogii, a decrease in environmental $\mathrm{pH}$ caused a non-significant reduction in pore radius and valve porosity on the inner side of the valve [39]. In the pennate diatom Cocconeis placentula, an increase in salinity from 67 to 100 caused an increase in the size of pores located on the external valve from length $=490 \pm 6 \mathrm{~nm}$ and width $=$ $108 \pm 2 \mathrm{~nm}$ to length $=517 \pm 8 \mathrm{~nm}$ and width $=148 \pm 2$ $\mathrm{nm}$ [40]. In the present study, temperature was controlled throughout the experiment, and salinity will not change during a short term experiment at moderate temperature. Relevant differences in $\mathrm{pH}$ are not expected, as the growth rates and the maximum cell concentration are not very different among the treatments. Therefore, temperature, $\mathrm{pH}$ and salinity can be excluded as the cause for the observed changes in nanostructure. Frustule nanostructural changes, either foramen density reductions or size reductions, might be related to the variation in silica deposition patterns as silicification is affected by cell growth and hence also by abiotic factors like light $[4,20,41]$. Controlling the light condition or other abiotic factors offers a possibility for manipulating frustule structure. It is thus clear that we may use abiotic factors to modify frustule patterns, but the implications for potential applications of the variability within each parameter are still unclear. Low variation in central morphological parameters may be an important criterion in selecting potential diatom species for optical application.

\subsection{Influence of morphology on the photonic properties of frustules}

It has been suggested earlier that the microstructure of the foramen results in multiple interference points if coherent monochromatic laser light is transmitted through a single frustule [42]. $\mathrm{R}$ and $\mathrm{W}$ light at 300 $\mu \mathrm{mol}$ photons $\mathrm{m}^{-2} \mathrm{~s}^{-1}$ resulted in the lowest and the highest foramen density, respectively (Fig. 3b). Therefore, the morphological parameters of frustules grown under these two light conditions were chosen for the simulation study to test whether the differences in morphology would induce a significant difference in the photonic properties of the frustules.

Figure 4 (a) shows a cross section of the light intensity from a plane wave at $\mathrm{z}$ distance after a frustule; the models of the frustules grown at $\mathrm{R}$ and $\mathrm{W}$ light were used in the top and bottom plot, respectively. The interference points of the microstructure are clearly visible at transverse position $0 \mu \mathrm{m}$, and the difference between the two frustule models is identified by the difference in distance of the interference points from the frustule at $z=0 \mu \mathrm{m}$ in each plot. The color scale is in $\mathrm{dB}$ relative to the input light intensity. In the top plot of Fig. $4 \mathrm{~b}$, where the relative light intensity of both simulations is plotted on a linear scale vs. $z$ from 100 $\mu \mathrm{m}-800 \mu \mathrm{m}$, the difference between the results of the two frustules is clearly visible: the intensity of the W light grown frustule (solid black) oscillates faster than that of the R light grown frustule (dashed red). Also, the light scattered by the latter is diffracted more outwards, so the intensity is lower than that of the $\mathrm{W}$ light grown frustule. In the bottom of Fig. $4 \mathrm{~b}$, the three insets show: (1) the model of the W light grown frustule used in the simulations, where white denotes the transparent holes and black denotes the opaque glass; (2) a zoom on the mask that shows the hexagonal pattern of the holes; and (3) the field 
intensity distribution in a plane parallel to and at a distance $z=300 \mu \mathrm{m}$ from the $\mathrm{W}$ light grown frustule. These results show that the changes in mean morphological parameters induced by growth in monochromatic light are not only statistically significant but also are of a magnitude large enough to induce measurable effects on the photonic properties of the frustules.

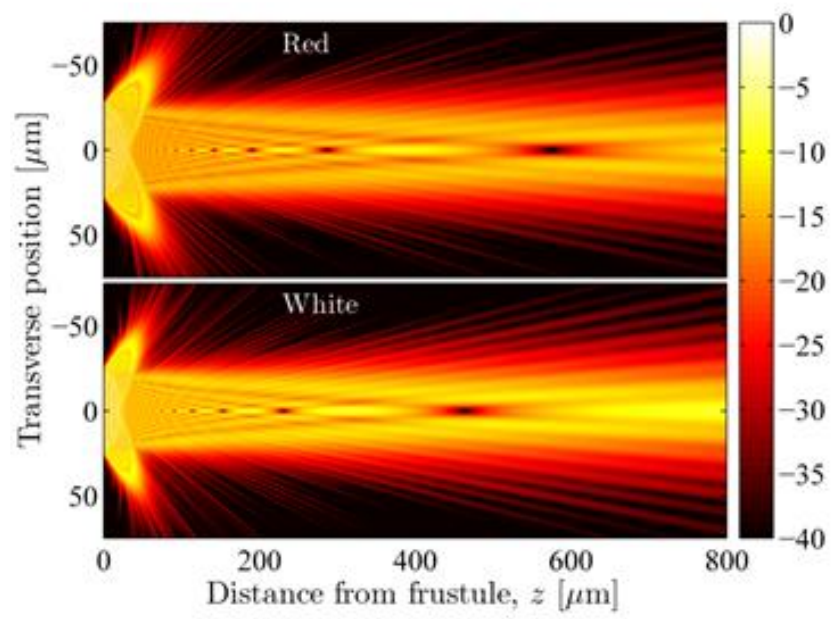

a
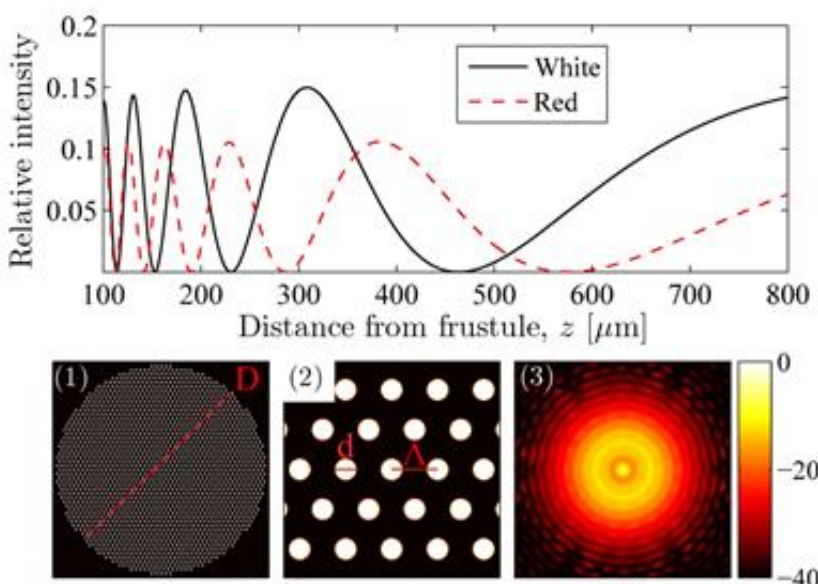

Frustule mask Zoom on structure $z=300 \mu \mathrm{m}$

b

Figure 4 Simulations of light propagation through a simplified frustule model. (a) Cross sections of the light intensity after each frustule $\left(300 \mu \mathrm{mol}\right.$ photons $\mathrm{m}^{-2} \mathrm{~s}^{-1} \mathrm{R}$ and $\left.\mathrm{W}\right)$; (b) The top plot shows intensity relative to the input intensity vs. distance to each frustule at transverse position $0 \mu \mathrm{m}$ in A. Inset (1) shows the simplified frustule hole pattern used for the simulation of the frustule grown in white light; inset (2) a zoom on the structure to visualize the hexagonal pattern; and inset (3) an image of the intensity in the transverse plane at distance $z=300 \mu \mathrm{m}$ from the frustule. The color scales are in $\mathrm{dB}$ relative to the input intensity.

The possible mechanism behind the morphological change might be a reaction of the diatom under the environmental stress because of the monochromatic light. The numerical simulation work can further show that under the illumination of different light wavelength, the diatom can change its frustule nanostructure to adjust the light distribution in its cell. This might play an important role in diatom evolution. The underlying molecular mechanism behind this response may be tested by e.g. gene expression analyses in the future.

\section{Conclusions}

This study demonstrated the response of frustule morphology and growth rate to different combinations of six light wavelengths and two intensities. The use of different light conditions was shown to be a potential method for manipulating the nanostructure of diatom frustules. Numerical simulations confirmed that the morphological changes obtained were sufficient to induce clear differences in the photonic properties of the frustules. This study provides a unique example of how cell culture systems can be light directed to produce natural materials with different nanostructures. This light stimulated method has the advantages of not needing additional chemicals compared with chemical based methods and being a simple operation of changing irradiance condition during diatom growth. In addition, the use of wavelength specific LED lights for growth may reduce the cost of cultivating diatoms for industrial application.

\section{Materials and methods}

\subsection{Cultures}

The genus Coscinodiscus has been explored for its potential in optical applications [9, 43], and was chosen in this study for its large frustule size and flat valve. The diatom species Coscinodiscus granii (strain K-1834) was obtained from the Scandinavian Culture Collection of Algae \& Protozoa. The strain was kept at $20{ }^{\circ} \mathrm{C}$ and $100 \mu \mathrm{mol}$ photons $\mathrm{m}^{-2} \mathrm{~s}^{-1}$ (Panasonic FL40ss Enw/37, Japan) with a light/dark cycle of $16 \mathrm{~h} / 8 \mathrm{~h}$. The growth medium was L1 medium with a salinity of 30 prepared with autoclaved seawater [44].

\subsection{Experimental setup and operation}


LEDs with five different light wavelengths including B (455 nm), G (528 nm), Y (590 nm), RO (617 nm) and $\mathrm{R}(654 \mathrm{~nm})$ (OSRAM, UK), which cover the range of visible light, were employed as illumination. The White light $(\mathrm{W})$ was used as control. The LEDs were mounted at the back of lightproof boxes (Fig.5). For each wavelength, two light intensities (300 and 100 $\mu \mathrm{mol}$ photons $\mathrm{m}^{-2} \mathrm{~s}^{-1}$ ) were investigated (measured with universal light meter, ULM-500, WALZ, Germany). The boxes were placed in incubators (MLR-352, Panasonic, Japan) at a stable temperature $\left(20 \pm 1{ }^{\circ} \mathrm{C}\right)$ throughout the test. After one week of acclimation at each combination of wavelength and light intensity, triplicate BD Falcon flasks with $50 \mathrm{ml}$ of L1 medium (salinity $=30$ ) at an initial $\mathrm{pH}$ of 8.0 were inoculated with $C$. granii cells from exponentially growing cultures. The initial concentration was $30 \pm 2$ cells $\mathrm{ml}^{-1}$.

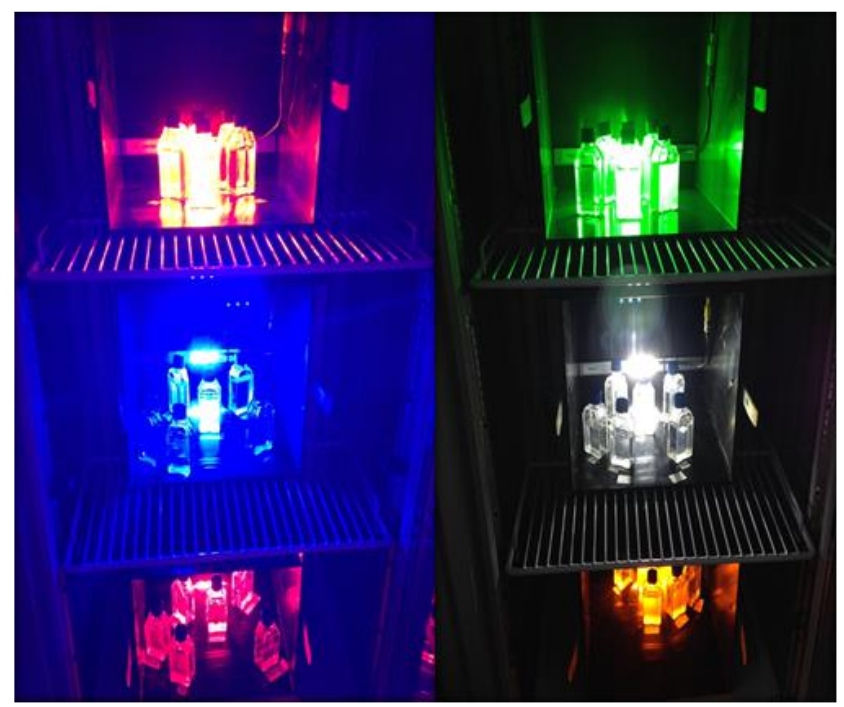

Figure 5 Photoimage of diatom culture system under different light conditions.

\subsection{Diatom growth, morphology analysis with TEM}

Subsamples of $1.2 \mathrm{ml}$ were taken daily and fixed in Lugol's solution (final concentration $2 \%$ ). The fixed samples were counted in a Sedgewick rafter. The maximum growth rate $(\mu)$ was calculated for each flask using the algorithm $\mu=\ln \left(N_{t 2} / N_{t 1}\right) /\left(t_{2}-t_{1}\right)$, where $N_{t 2}$ and $N_{t 1}$ represent cell numbers at times $t_{2}$ and $t_{1}$ using only the steepest part of the exponential growth curve. For each combination of wavelength and light intensity, mean and standard deviation was calculated based on growth rates of the triplicates.

After 10 days, $10 \mathrm{ml}$ of cells from each combination of growth conditions were acid cleaned in order to remove the organic matter and the frustules were collected for morphological studies [45, 46]. The material was mounted on copper grids, and the cleaned frustules examined using a JEM-1010 (Jeol, Japan) Transmission Electron Microscope (TEM). The test was repeated twice. Frustule diameter, foramen number in $10 \mu \mathrm{m}$ (foramen density) and the diameter of the foramen were measured on 20 frustules (10 frustules for each batch) from each light treatment and average values were calculated. Morphometric data were analyzed by ANOVA or by Kruskall Wallis test, if the data were not normally distributed (IBM SPSS Statistics).

\subsection{Numerical simulation}

A wavelength of $632.8 \mathrm{~nm}$ (He-Ne red) was used to simulate the propagation of light in free space through a frustule of average proportions grown at $300 \mu \mathrm{mol}$ photons $\mathrm{m}^{-2} \mathrm{~s}^{-1}$ in red and white light, respectively. The simulations are based on a full diffraction algorithm [47] in which the usual simplifying analytical approximations (Fresnel and Fraunhofer) are not made. In the simplistic picture applied, a frustule is modelled as a circular shaped array with a diameter $D$ of holes in a hexagonal pattern. The parameters of the two aforementioned frustules were used. For R light, $D$ (frustule diameter) $=54.65 \mu \mathrm{m}, d$ (foramen diameter) $=519.6 \mathrm{~nm}$ and $\Lambda$ (periodicity of adjacent foramen) $=1.212 \mu \mathrm{m}$; for the frustule grown in $W$ light, $D=48.72 \mu \mathrm{m}, d=498.7 \mathrm{~nm}$ and $\Lambda=1.065 \mu \mathrm{m}$. The holes are assumed to be completely transparent, while the non-hole area is assumed opaque, and a resolution of 32 pixels per $\mu \mathrm{m}$ was used.

\section{Acknowledgements}

This study was funded by FTP project no. 12-127569 (ALgal PHotonics Applications: ALPHA).

Electronic Supplementary Material: Supplementary material (Table S1: maximum growth rates under different light treatments and Table S2: frustule morphology parameters under different light 
treatments) is available in the online version of this article at http://dx.doi.org/10.1007/s12274_***_****_*. (automatically inserted by the publisher).

\section{References}

[1] Nelson, D. M.; Treguer, P.; Brzezinski, M. A.; Leynaert, A.; Queguiner, B. Production and dissolution of biogenic silica in ocean - revised global estimates, comparison with regional data and relationship to biogenic sedimentation. Global. Biogeochem. Cy. 1995, 9, 359-372.

[2] Li, H. Y.; Lu, Y.; Zheng, J. W.; Yang, W. D.; Liu, J. S. Biochemical and Genetic Engineering of Diatoms for Polyunsaturated Fatty Acid Biosynthesis. Mar. Drugs. 2014, 12, 153-166.

[3] Guiry, M. D. How many species of algae are there? $J$. Phycol. 2012, 48, 1057-1063.

[4] Martin-Jezequel, V.; Hildebrand, M.; Brzezinski, M. A. Silicon metabolism in diatoms: implications for growth. $J$. Phycol. 2000, 36, 821-840.

[5] Kröger, N.; Sumper, M. The molecular basis of diatom biosilica formation. In Biomineralization: Progress in Biology, Molecular Biology and Application; Bäuerlein, E., $2^{\text {nd }}$ Eds.; SBN: 978-3-527-60461-6, pp137-158.

[6] Round, E. F., Crawford, M. R., Mann, G. D. The diatoms biology \& morphology of the genera. Cambridge University Press: New York, 1990.

[7] Kroger, N.; Poulsen, N. Diatoms-from cell wall biogenesis to nanotechnology. Annu Rev Genet. 2008, 42, 83-107.

[8] Lettieri, S.; Setaro, A.; De Stefano, L.; De Stefano, M.; Maddalena, P. The gas-detection properties of light-emitting diatoms. Adv. Funct. Mater. 2008, 18, $1257-1264$.

[9] De Stefano, L.; De Stefano, M.; Maddalena, P.; Moretti, L.; Rea, I.; Mocella, V.; Rendina, I. Playing with light in diatoms: small water organisms with a natural photonic crystal structure. Proc. SPIE, 2007, 6593, 59313.

[10] De Stefano, L.; Rea, I.; Rendina, I.; De Stefano, M.; Moretti, L. Lensless light focusing with the centric marine diatom Coscinodiscus walesii. Opt. Express. 2007, 15, 18082-18088.

[11] Oh, S. J.; Kim, D. I.; Sajima, T.; Shimasaki, Y.; Matsuyama, Y.; Oshima, Y.; Honjo, T.; Yang, H. S. Effects of irradiance of various wavelengths from light-emitting diodes on the growth of the harmful dinoflagellate Heterocapsa circularisquama and the diatom Skeletonema costatum. Fisheries Sci. 2008, 74, 137-145.

[12] Kieu, K.; Li, C.; Fang, Y.; Cohoon, G.; Herrera, O. D.; Hildebrand, M.; Sandhage, K. H.; Norwood, R. A. Structure-based optical filtering by the silica microshell of the centric marine diatom Coscinodiscus wailesii. Opt Express 2014, 22, 15992-15999.

[13] Ferrara, M. A.; Dardano, P.; De Stefano, L.; Rea, I.; Coppola, G.; Rendina, I.; Congestri, R.; Antonucci, A.; De Stefano, M.; De Tommasi, E. Optical properties of diatom nanostructured biosilica in Arachnoidiscus sp: micro-optics from mother nature. PloS One 2014, 9, 1-8.
[14] De Stefano, L.; Maddalena, P.; Moretti, L.; Rea, I.; Rendina, I.; De Tommasi, E.; Mocella, V.; De Stefano, M. Nano-biosilica from marine diatoms: a brand new Mmaterial for photonic applications. Superlattice Microst 2009, 46, 84-89.

[15] Qin, T.; Gutu, T.; Jiao, J.; Chang, C. H.; Rorrer, G. L. Biological fabrication of photoluminescent nanocomb structures by metabolic incorporation of germanium into the biosilica of the diatom Nitzschia Frustulum. Acs Nano 2008, 2, 1296-1304.

[16] Zhang, D. Y.; Wang, Y.; Cai, J.; Pan, J. F.; Jiang, X. G.; Jiang, Y. G. Bio-manufacturing technology based on diatom micro- and nanostructure. Chin. Sci. Bull. 2012, 57, 3836-3849.

[17] Losic, D.; Triani, G.; Evans, P. J.; Atanacio, A.; Mitchell, J. G.; Voelcker, N. H. Controlled pore structure modification of diatoms by atomic layer deposition of $\mathrm{TiO}_{2}$. J. Mater. Chem. 2006, 16, 4029-4034.

[18] Townley, H. E.; Woon, K. L.; Payne, F. P.; White-Cooper, H.; Parker, A. R. Modification of the physical and optical properties of the frustule of the Diatom Coscinodiscus wailesii by nickel sulfate. Nanotechnol. 2007, 18, 1-5.

[19] Jeffryes, C.; Gutu, T.; Jiao, J.; Rorrer, G. L. Metabolic insertion of nanostructured $\mathrm{TiO}_{2}$ into the patterned biosilica of the diatom Pinnularia sp by a two-stage bioreactor cultivation process. Acs Nano 2008, 2, 2103-2112.

[20] Hansen, L. R.; Soylu, S. I.; Kotaki, Y.; Moestrup, O.; Lundholm, N. Toxin production and temperature-induced morphological variation of the diatom Pseudo-nitzschia seriata from the arctic. Harmful Algae. 2011, 10, 689-696.

[21] Lewis, N. I.; Bates, S. S.; McLachlan, J. L.; Smith, J. C. Temperature Effects on Growth, Domoic Acid Production, and Morphology of The Diatom Nitzschia pungens $f$. nultiseries; Smayda, T.J., Shimizu, Y., Eds.; Amsterdam: Elsevier, 1993, 3, pp 601-606.

[22] De Stefano, M.; De Stefano, L.; Congestri, R. Functional morphology of micro and nanostructures in two distinct diatom frustules. Superlattices Microstruct. 2009, 46, 64-68.

[23] Parker, A. R.; Townley, H. E. Biomimetics of photonic nanostructures. Nat. Nanotechnol. 2007, 2, 347-353.

[24] Sumper, M.; Brunner, E. Learning from diatoms: nature's tools for the production of nanostructured silica. Adv. Funct. Mater. 2006, 16, 17-26.

[25] Mouget, J. L.; Rosa, P.; Tremblin, G. Acclimation of Haslea ostrearia to light of different spectral qualities confirmation of "chromatic adaptation" in diatoms. $J$. Photochem. Photobiol B. 2004, 75, 1-11.

[26] Mercado, J. M.; Sanchez-Saavedra, M. D.; Correa-Reyes, G.; Lubian, L.; Montero, O.; Figueroa, F. L. Blue light effect on growth, light absorption characteristics and photosynthesis of five benthic diatom strains. Aquat Bot. 2004, 78, 265-277.

[27] Glover, H. E.; Keller, M. D.; Spinrad, R. W. The effects of light quality and intensity on photosynthes is and growth of marine eukaryotic and prokaryotic phytoplankton clones. $J$. Exp. Mar. Biol. Ecol. 1987, 105, 137-159.

[28] Wallen, D. G.; Geen, G. H. Light quality in relation to growth, photosynthetic rates and carbon metabolism in 2 
speices of marine plankton algae. Mar. Biol. 1971, 10, 34-43.

[29] Wallen, D. G.; Geen, G. H. Light quality and concentration of proteins, RNA, DNA and photosynthetic pigments in 2 species of marine plankton algae. Mar. Biol. 1971, 10, 44-51.

[30] Keeling, P.J. The Number, Speed, and Impact of Plastid Endosymbioses in Eukaryotic Evolution. Annu. Rev. Plant Biol. 2013, 64, 583-607.

[31] Olle, M.; Viršile, A. The effects of light-emitting diode lighting on greenhouse plant growth and quality. Agric. Food Sci. 2013, 22, 223-234.

[32] Schulze, P. S. C.; Barreira, L. A.; Pereira, H. G. C.; Perales, J. A.; Varela, J. C. S. Light emitting diodes (LEDs) applied to microalgal production. Trends Biotechnol. 2014, 32, 423-431.

[33] Blanken, W.; Cuaresma, M.; Wijffels, R. H.; Janssen, M. Cultivation of microalgae on artificial light comes at a cost. Algal Res. 2013, 2, 333-340.

[34] Taylor, N. J. Silica incorporation in the diatom Coscinodiscus granii as affected by light intensity. Brit. Phycol. J. 1985, 20, 365-374.

[35] Tomas, C. Identifying Marine Phytoplankton. Academic Press: 1997.

[36] Jung, S. W.; Youn, S. J.; Shin, H. H.; Yun, S. M.; Ki, J. S.; Lee, J. H. Effect of temperature on changes in size and morphology of the marine diatom, Ditylum brightwellii (west) grunow (Bacillariophyceae). Estuar. Coast. Shelf. S. 2013, 135, 128-136.

[37] Falasco, E.; Bona, F.; Badino, G.; Hoffmann, L.; Ector, L. Diatom teratological forms and environmental alterations: a review. Hydrobiologia. 2009, 623, 1-35.

[38] Villareal, T. A.; Fryxell, G. A. Temperature Effects on The Valve Structure of The Bipolar Diatoms Thalassiosira
Antarctica and Porosira glacialis. Polar Biol. 1983, 2, 163-169.

[39] Herve, V.; Derr, J.; Douady, S.; Quinet, M.; Moisan, L.; Lopez, P. J. Multiparametric analyses reveal the $\mathrm{pH}$-dependence of silicon biomineralization in diatoms. Plos One 2012, 7, 1-12.

[40] Leterme, S. C.; Ellis, A. V.; Mitchell, J. G.; Buscot, M. J.; Pollet, T.; Schapira, M.; Seuront, L. Morphological flexibility of Cocconeis placentula (Bacillariophyceae) nanostructure to changing salinity levels. J. Phycol. 2010, 46, 715-719.

[41] Cattaneo, A.; Couillard, Y.; Wunsam, S.; Courcelles, M. Diatom taxonomic and morphological changes as indicators of metal pollution and recovery in Lac Dufault (Quebec, Canada). J. Paleolimnol. 2004, 32, 163-175.

[42] De Tommasi, E.; Rea, I.; Mocella, V.; Moretti, L.; De Stefano, M.; Rendina, I.; De Stefano, L. Multi-wavelength study of light transmitted through a single marine centric diatom. Opt. Express. 2010, 18, 12203-12212.

[43] Noyes, J.; Sumper, M.; Vukusic, P. Light manipulation in a marine diatom. J. Mater. Res. 2008, 23, 3229-3235.

[44] Guillard, R. R. L.; Hargraves, P. E. Stichochrysis Immobilis is a diatom, not a Chrysophyte. Phycologia. 1993, 32, 234-236.

[45] Christensen, T. Alger i Naturen og i Laboratoriet. Københavns Universitet/ Institut for Sporeplanter. 1988; pp 137.

[46] Hasle, G. R.; Fryxell, G. A. Diatom: cleaning and mounting for light and electron microscopy. Trans Am Microsc Soc. 1970, 89, 469-474.

[47] Delen, N.; Hooker, B. Free-space beam propagation between arbitrarily oriented planes based on full diffraction the ory: a fast fourier transform approach. J. Opt. Soc. Am. Optic. Image. Sci. Vis. 1998, 15, 857-867. 


\section{Electronic Supplementary Material}

\section{Implications for photonic applications of diatom growth and frustule nanostructure changes in response to different light wavelengths}

Yanyan Su${ }^{1}(\varangle)$, Nina Lundholm², Søren M.M. Friis ${ }^{3}$, and Marianne Ellegaard ${ }^{1}$

'Department of Plant and Environmental Sciences, University of Copenhagen, Thorvaldsensvej40, 1871 Frederiksberg, Denmark

${ }^{2}$ Natural History Museum of Denmark, University of Copenhagen, Sølvgade 83S, DK-1307 Copenhagen K, Denmark

${ }^{3}$ Department of Photonics Engineering, Technical University of Denmark, Ørsteds Plads 343, 2800 Kongens Lyngby, Denmark

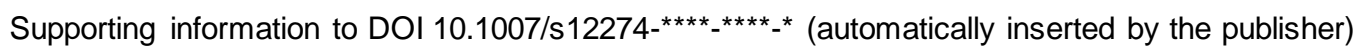

Table S1. Maximum growth rate under different light treatment. The numbers indicated mean \pm SD.

\begin{tabular}{llllllll} 
Light intensity & & & & & \\
& Red & Red-orange & Yellow & Green & Blue & White & Significant \\
$\left(\mu\right.$ mol photons $\left.\mathrm{m}^{-2} \mathrm{~s}^{-1}\right)$ & & & & & & & \\
\hline 300 & $0.914 \pm 0.017$ & $0.872 \pm 0.010$ & $0.837 \pm 0.010$ & $0.932 \pm 0.005$ & $0.948 \pm 0.041$ & $0.892 \pm 0.089$ & No \\
100 & & & & & & & \\
& $0.826 \pm 0.052$ & $0.656 \pm 0.046$ & $0.486 \pm 0.098$ & $0.690 \pm 0.016$ & $0.874 \pm 0.022$ & $0.709 \pm 0.047$ & Yes \\
\hline
\end{tabular}


Table S2. Frustule morphology parameters under different light treatment. The numbers indicated mean \pm SD. $\mathrm{p}$ value in bracket indicated the significance between the results of repeated examination by ANOVA or Kruskall Wallis test. Critical value $(\alpha)$ is 0.05 .

\begin{tabular}{|c|c|c|c|c|c|c|c|c|}
\hline & $\begin{array}{l}\mu \mathrm{mol} \\
\text { photons } \\
\mathrm{m}^{-2} \mathrm{~s}^{-1}\end{array}$ & Red & Red-orange & Yellow & Green & Blue & White & Significant \\
\hline $\begin{array}{l}\text { Frustule } \\
\text { diameter }\end{array}$ & 300 & $\begin{array}{l}54.65 \pm 24.61 \\
(p=0.78)\end{array}$ & $\begin{array}{l}46.76 \pm 7.89 \\
(p=0.95)\end{array}$ & $\begin{array}{l}53.34 \pm 28.85 \\
(p=0.77)\end{array}$ & $\begin{array}{l}42.61 \pm 5.60 \\
(p=0.53)\end{array}$ & $\begin{array}{l}46.79 \pm 8.05 \\
(p=0.73)\end{array}$ & $\begin{array}{l}48.72 \pm 6.19 \\
(p=0.48)\end{array}$ & No \\
\hline$(\mu \mathrm{m})$ & 100 & $\begin{array}{l}60.80 \pm 33.58 \\
(p=0.80)\end{array}$ & $\begin{array}{l}48.01 \pm 9.17 \\
(p=0.93)\end{array}$ & $\begin{array}{l}51.45 \pm 21.94 \\
(p=0.89)\end{array}$ & $\begin{array}{l}42.70 \pm 5.71 \\
(p=0.77)\end{array}$ & $\begin{array}{l}49.16 \pm 33.28 \\
(p=0.67)\end{array}$ & $\begin{array}{l}64.44 \pm 41.09 \\
(0.72)\end{array}$ & Yes \\
\hline $\begin{array}{l}\text { Foramen } \\
\text { density }\end{array}$ & 300 & $\begin{array}{l}8.25 \pm 1.08 \\
(p=0.67)\end{array}$ & $\begin{array}{l}8.93 \pm 1.04 \\
(p=0.64)\end{array}$ & $\begin{array}{l}8.44 \pm 0.60 \\
(p=0.92)\end{array}$ & $\begin{array}{l}8.36 \pm 0.78 \\
(p=0.39)\end{array}$ & $\begin{array}{l}8.73 \pm 0.42 \\
(p=0.64)\end{array}$ & $\begin{array}{l}9.39 \pm 0.59 \\
(p=0.49)\end{array}$ & Yes \\
\hline$(/ 10 \mu \mathrm{m})$ & 100 & $\begin{array}{l}9.00 \pm 0.69 \\
(p=0.83)\end{array}$ & $\begin{array}{l}9.07 \pm 0.69 \\
(p=0.81)\end{array}$ & $\begin{array}{l}9.12 \pm 0.58 \\
(p=0.71)\end{array}$ & $\begin{array}{l}9.01 \pm 0.45 \\
(p=0.43)\end{array}$ & $\begin{array}{l}9.01 \pm 0.61 \\
(p=0.66)\end{array}$ & $\begin{array}{l}8.47 \pm 0.95 \\
(p=0.12)\end{array}$ & No \\
\hline $\begin{array}{l}\text { Foramen } \\
\text { diameter }\end{array}$ & 300 & $\begin{array}{l}519.57 \pm 56.82 \\
(p=0.73)\end{array}$ & $\begin{array}{l}488.71 \pm 44.40 \\
(p=0.76)\end{array}$ & $\begin{array}{l}486.47 \pm 48.87 \\
(p=0.81)\end{array}$ & $\begin{array}{l}481.08 \pm 49.89 \\
(p=0.90)\end{array}$ & $\begin{array}{l}495.77 \pm 37.51 \\
(p=0.70)\end{array}$ & $\begin{array}{l}498.72 \pm 44.09 \\
(p=0.85)\end{array}$ & No \\
\hline$(\mathrm{nm})$ & 100 & $\begin{array}{l}534.80 \pm 63.15 \\
(p=0.91)\end{array}$ & $\begin{array}{l}506.66 \pm 43.59 \\
(p=0.80)\end{array}$ & $\begin{array}{l}535.52 \pm 64.37 \\
(p=0.89)\end{array}$ & $\begin{array}{l}489.66 \pm 50.22 \\
(p=0.69)\end{array}$ & $\begin{array}{l}508.86 \pm 51.75 \\
(\mathrm{p}=0.84)\end{array}$ & $\begin{array}{l}546.81 \pm 64.92 \\
(p=0.81)\end{array}$ & Yes \\
\hline
\end{tabular}

